lioness was seen perched in a large tree some $\mathbf{4 0}$ feet above the ground. She had a grand view of the surrounding country. Here also are many kob, topi and waterbuck. A red forest duiker was seen and also three whale-billed storks. Bushbuck and wart-hog were very numerous. All the game was inclined to be wild, no doubt due to poaching and probably due also to the number of animals which I understand were shot to supply meat to the labour building the road. This area will need close control before it is too late.

\title{
THE BEHAVIOUR OF SELADANG (Bibos gaurus)
}

\section{By C. S. Ogilvie, Game Warden, Federation of Malaya}

Reaction to the Presence of Man and of Tiger.-Bull seladang grazing in the open seldom raise their heads from the serious business of filling their maws, but leave watch-dog duties to the cows. The latter seldom keep their heads down long, and it is on this account that care must be taken when stalking a herd up wind in the open. Some cow almost always has her head up looking about. I say " looking about", for they do not generally try the wind unless some strange or dangerous scent comes to them; then all, even the bulls, are on their toes. When an unfavourable wind is received they first throw up their heads and face into the wind, raising their noses ; after a good inspiration in this position, they swing their heads sharply first to one side, then after a short pause to the other side, testing the wind. They may repeat this action several times before being certain. From this they are able to determine the direction in which any danger may lie. If it is a scent denoting the presence of man they hesitate not on the order of going, stampeding away from the dreaded scent for perhaps seventy or a hundred yards. After their initial rush they pull up for a short pause making sure the danger is not on their tails. If the danger is not so close, they slip quietly away at a fast walk; if the source of danger is not following they keep this up, perhaps, for several miles, before they pull up for a real breather, but still remain very wary.

With tiger they respond very differently. To illustrate this I will recount an experience I had in the Krau game reserve before the Japanese invasion. One evening I was approaching an old "Jah Chong" 1 clearing which seladang used to frequent.

1 Local aboriginal tribe. 
When within a hundred yards of the clearing's edge I heard a bull seladang bellow. I made my approach even more stealthily and came to the clearing's edge, at which point there was a large and high termite's nest, with sparse lalang ${ }^{1}$ grass growing about its base ; this was so sparse it could not have provided cover for a Skye terrier. I edged to the right and moved forward to view the clearing better, but could see no seladang to my front. As I edged further forward to get a view round the anthill, a startled sambur deer bellowed in my right ear and raced away across the clearing. Startled by the sudden terrific noise I jumped, and a moment later was peering round the anthill, where at about forty paces stood a herd of eight seladang, including a fine old bull. All heads were up and looking in the direction of the startled sambur. After counting the seladang several times and making a mind picture of them for my notes, I turned back to signal to a young ranger who had not yet seen seladang. As I raised my hand and beckoned, a tiger rose from a prone position at the base of the anthill and leapt out of sight giving an angry " ahauh". With nothing but a tiny Malay golok in my hand, my reaction does not concern this narrative, but when I was able to collect my wits I turned back to see what the seladang were doing. They were still there and had moved forward five or six paces in the direction of the tiger's angry voice. In doing so they had bunched, with the bull half a length forward, cows to the right and left while the smaller fry could barely be seen in the knot. I am afraid I was careless; at any rate I was so engrossed that I exposed myself to them and they undoubtedly mistook me for the tiger and approached menacingly but slowly. I was flummoxed and backed slowly into the open. They stopped and glowered malevolently and while I continued my slow walk backwards, still stood their ground (they had not my scent as the wind was from them). I still continued backwards while they remained closely bunched, glaring balefully across the short intervening space; the space widened and eventually $I$ found myself in the cover of the forest. My two companions had already made themselves scarce on seeing the tiger, and I do not believe that the new ranger has seen seladang yet.

Seladang under normal conditions fear man, and either sound or sight of him is enough to set them on the run. Not so where tigers are concerned; they may fear tiger, and undoubtedly there are losses from the herd on the tiger's account, but they know their combined strength and are prepared to

1 Imperata cylindrica. 
stand and fight rather than run. The tiger mentioned here would have been shredded, had he attacked that knot of angry beasts. In passing it might be noted how invisible tigers may be. How all three of us failed to notice this one was beyond our understanding. How that beast stayed frozen while I chased away its dinner the sambur, walked past its nose, and then came back and stood beside it beckoning, is still beyond my comprehension; but the fact remains that practically standing on its toes proved the last straw. I was not its meat and the tiger went; but I do think angrily.

Behaviour at an Artificial Salt Lick.-Eight head of seladang were out behind my house by 4 p.m. At 5 p.m. they lay in the grass chewing the cud. It was only when they moved that the part of their heads showing did not look like weathered stumps. At 6 p.m. they stood up and proceeded to the salt hole and enjoyed the salt put out for them. We make use of specially prepared bricks of cattle salt produced by Imperial Chemical Industries, Ltd. Our cattle (seladang) are most keen on this and appear to thrive on their intake of it. It is generally turn and turn about with the salt ; all make way for an old bull when he wants a dose, and the youngsters give way to the cows. Woe betide the calf who is at the medicine box and fails to give way when the dam of another calf, or a spinster approaches. Many times $I$ have watched youngsters up to eighteen months old or more, chased at high speed by cows just because they had not moved away from the salt as soon as the cow considered they might have done. I have seen no serious wound or even lasting discomfort to any calf as a result of the buffeting received from "Aunty". This chasing of the youngsters by cows takes place also at the oddest of times for no reason apparent to me, but it does happen quite frequently, however, with cows advanced in pregnancy when approached too closely by earlier offspring. Calves, until they are quite big and in their dark brown coats, take no real interest in salt. Time and again I have watched a calf standing beside the dam while the latter was busy in my chemist shop ; the calves' only reaction being an occasional sniff at the bottles. 